\title{
Adopting the Factors That Motivate and Sustain Teachers Interest in the Teaching Profession for National Development in Education
}

\author{
Chinedu Ifeakor ${ }^{1}$, Anselm Ikenna Odo ${ }^{2}$ \\ ${ }^{1}$ Department of Philosophy, Nnamdi Azikiwe University, Awka, Nigeria. \\ ${ }^{2}$ Department of Educational Foundations, Philosophy of Education Unit \\ Nasarawa State University, Keffi \\ Email: cs.Ifeakor@uniz.edu.ng ${ }^{1}$, anselmikenna4us@ gmail.com ${ }^{2}$
}

\begin{abstract}
This paper sought to adopt the factors that motivate and sustain the teacher's interest in the teaching profession. This is as a result of a vivid nonchalant attitude exhibited by some of the Nigeria teachers. First, the effect of irregular payment of teachers' salaries has cause an alarm for the performance of teachers in work. Again, the inadequate promotion of teachers has negative impact in discharging their duties effectively and efficiently, thus this leads to teachers' low standard of living and sometimes abandons the teaching profession and they look for better paid job. The negligent of teachers' welfare affect their service and it is cause by the attitude of all that are concern in the school as government the school administrators, school heads even the society at large who does not encourage teachers to put in their best. With these, the researchers adopt expository and descriptive method in carrying out this work. The authors recommend that school heads should make use of correct motivation strategies such as attitude motivation and recognition. Also autocratic/dictatorship leadership style should be discouraged. Again, society should respect and recognize teachers' position in nation building equally communities should see the school as an institution that inculcate into individual society's value and norms and see it a responsibility to donate its welfare.
\end{abstract}

Keywords: Motivate; Teacher; Interest

\section{INTRODUCTION}

The vivid nonchalant attitude exhibited by some of the Nigeria teachers has call to mind on the cause of the showed action. This goes with the saying that there is no smoke without fire. It is notably that the effect of irregular payment of teachers' salaries has cause an alarm for the performance of teachers in work. Again, the inadequate promotion of teachers has negative impact in discharging their duties effectively and efficiently, thus this leads to teachers' low standard of living and sometimes abandons the teaching profession and they look for better paid job. The negligent of teachers' welfare affect their service and it is caused by the attitude of all that are concern in the school as government the school administrators, school heads even the society at large who does not encourage teachers to put in their best. 


\author{
46| Jurnal Office: Jurnal Pemikiran Ilmiah dan Pendidikan Administrasi Perkantoran \\ Vol. 6, No. 1, January-June 2020, Page 45-52
}

\title{
CLARIFICATION OF CONCEPTS
}

\section{Motivation}

Motivation is a theoretical construct used to explain behavior in living things. It gives the reason for people's action, desires and need. It gives one direction to behavior or what cause a person want to repeat a behavior and vice versa. It is a force that guides, but why exactly are we motivated to do the things we do? It is a psychological phenomenon, which means need and wants of an individual or a learner being tackled in the right direction. The concept of "Motivation" comes from the Latin word "mooveers" which when interpreted means to move. We can then conclude that its literal meaning, motivation is the process of arousing or attracting in people towards the achievement of some goals. Vernon (1999) defines motivation as "the hidden urge within us which compel us to behave in a certain way such as may be purely instinctive that emanates within us. Wandy (2008) on the other hand, says that motivation is seen as a reason, incentives, enthusiasm, or interest that causes a specific action or certain behavior in people. Deducing from their points, the motivation can be seen as a techniques used to arouse the interest of an individual over a particular something.

\section{Types of Motivation}

Motivation can be divided into two according to Coon and Mitterer (2010); Intrinsic motivation and Extrinsic motivation. Intrinsic Motivation: this involves performing an action because you enjoy it not because you are trying to earn a reward. It refers to behaviour that is driven by internal reward.

1. Intrinsic motivation occurs when we act without any obvious external reward. We simply enjoy an activity or see it as an opportunity to explore learn and actualize our potentials (Coon and Mitterer, 2010). Intrinsic motivation refers to the reason why we perform certain activities for inherent satisfaction or pleasure (Brown, 2007).

\section{Some factors that are identified that increase intrinsic motivation are:}

a. Challenge: people are more motivated when they pursue goals that have personal meaning; that relates to their self- esteem when performance feedback is available and when attaining the goal is possible but not necessarily certain.

b. Curiosity: internal motivation is increased when something in the physical environment grabs the individual's attention (sensory curiosity) and when something about the activity stimulates the person to want to learn more (cognitive curiosity)

c. Control: people want control over themselves and their environments and want to determine what they pursue. 
d. Cooperation and Competition: intrinsic motivation can be increased in situations where people get satisfaction from helping others and compare their own performance favourably to that of others.

e. Recognition: people enjoy having their accomplishment recognized by others and this can increase internal motivation.

f. Observation: it has been observed that offering unnecessary rewards can have unexpected cost.

2. Extrinsic Motivation: This is a way of providing satisfaction, independent of learning activity itself. It refers to behaviour that is driven by external rewards such as money, fame, grades, and praises. People who are extrinsically motivated will continue to perform an action even though the task might be in and of itself rewarding.

Extrinsic motivation is usually defined as our tendency to engage in activities in order to gain some types of known, external reward. This reward can either be tangible or psychological in nature. Money and trophies are two common types of tangible rewards. Psychological forms of extrinsic motivation can include praise and public acclaim. A child might clean her room in order to receive positive praise from her parents. Offering money, grades, promotion or gift to motivate students to study harder promotes extrinsic motivation. Extrinsic motivation is often applied by the teacher; it serves to increase attention and achievement. Psychologist have discovered that students' motivation will be greatest in a situation in which both intrinsic and extrinsic rewards are present and are made used of, such that one does not interfere with the other. The teacher should encourage intrinsic motivation in all students who show signs of any and for students who have no intrinsic motivation to learn extrinsic reward.

\section{Factors influencing motivation}

There are lots of factors that influence motivation. However, Richard and Steer(1983) observed that it is not the responsibility of the teacher to create motives in the learners, rather his/her task is to take advantage of the motives always present in the learner and develop them towards the attainment of desirable objectives.

1. Physiological system of the organization: this is one of the factors that influence motivation. It includes food, oxygen, water, elimination and warmth in the body. These factors govern all our primary need,which gives us different degree of motivation and prepare us for the quest and satisfaction of our secondary needs.

2. Emotions: Emotion is any relatively brief conscious experience characterized by intense mental activity and a high degree of pleasure displeasure. Emotions are state of feelings that result in physical and psychological changes that influences our bahaviour. Emotion is a driving force behind motivation, positive or negative. Emotions are not casual forces but simply syndromes of components which might include feelings, behaviour and physiological changes. Emotion is an affective state of consciousness in which joy, sorrow, fear, hate, or the like is experienced as distinguished from cognitive and volitional state of consciousness.

3. Habit: it works as motivator but not all habit work as motivators, only those habits activates and regulates our action in a dynamic sense may be termed as motivators. All forms of 


\section{$48 \mid$ Jurnal Office: Jurnal Pemikiran Ilmiah dan Pendidikan Administrasi Perkantoran \\ Vol. 6, No. 1, January-June 2020, Page 45-52}

negative habits do not in any way help in achieving successful motivated behaviour which teachers should discourage.

4. Interest: this is closely related to habit and motives because they are acquired as a result of satisfying experience in a given authority. They are therefore related to such factors as age, sex, and background. One of the primary responsibilities of the school is the fostering of new purpose, new motives and new interest.

5. Incentives: this is another factor influencing motivation. These are objects or conditions which have possibilities in terms of satisfying motives and which therefore becomes goals towards which behaviour is directed (Richard and Steer 1983).

\section{The concept of Teacher}

A teacher is the only person who is capable of imparting knowledge and shaping the youths to the wider scope of knowledge. Teachers are capable of living and moulding the youths such that their power is paramount as they determine the fate of the society. Both teachers and parents live with the children for a long time and hence they are capable of imparting knowledge, skills an values that cannot be easily challenged by the society.

\section{Qualities of a Good Teacher}

1. Should be knowledgeable in terms of what he/she is teaching. A good teacher is the one who knows exactly what he is teaching. The teacher who is knowledgeable will be able to teach opposed to one who does not know his/her subject matter. Apart from possessing the knowledge of the subject matter/lesson, a teacher is also expected to have skills that will enable him/her to administer the teaching and learning process without any problem. Also the teacher is expected to promote and nurture different potentials among pupils.

2. Love of justice and democracy unnecessarily. The teacher who loves justice treats all the students fairly. The pupils will complain if a teacher favours some pupils while punishing others. For example, it will be ridiculous for a teacher who will decide to punish pupils who play football in the classroom and spare those who make noise. Pupils are aware of this situation and a teacher therefore is advised to be careful so as to avoid being labeled a dictator. The teacher is required to involve all pupils in the learning the teaching strategies should be applied so as to promote creativity and an inquiry mind among pupils.

3. Should be a role model. A good teacher should be a role model to the pupils (Irek 2018). The teacher should have a hard working spirit, should be diligent. Teacher should not be expect to be lazy, an alcoholic, a thief, brutal, harsh and a dictator. In terms of decision making the person demonstrating the above named manners does not qualify to be called a teacher because she/he will do nothing other than producing dictators and robbers in the society. Always pupils tend to emulate what the teacher does rather than what is said in the class (Tungaraza 2004).

4. Flexible and likes to learn more A teacher is supposed to have a reading culture so as to cope with the changes. A good teacher should be anxious to learn more so as to improve his teaching methodologies (Irek \& Charles 2015). It is equally important for a teacher to 
understand that everything is in Every day is a new day and the teacher therefore should appreciate the changes. Accepting change will help the teacher to have peace of mind since pupils expect much from him/her especially when it involves new things.

\section{Motivational Strategies For Teachers}

Smith opined that teachers by giving some kind of incentives are recognized as being effective. Incentives are often given in the form of money, prize, applause, gift and can be seen as part of the reward system designed to reinforce behaviour and therefore motivates learners to work towards the goals and objectives of the organization or school system.

The absence of motivation in a school setting will definitely hinder and slow the growth and competition among the students. Smith, (1973) in considering the economic basis of human motivation, believes that people work primarily for money and they are motivated to do only that which provides them with the greatest rewards. On the other hand, Okumbe, (1998) opined that motivation is a process that begins with deficiency that is psychological or a drive that is aimed at satisfying a goal. Marques, (2010) also hold that motivation is said to be what is required for people to perform better in any activity. Every educator need to be concerned about motivation. It is a quality that the teacher must have and be able to strategies and implement it in class room situation.

Today, academic performance has become the greatest gate keeper to higher learning institutions and secondary schools, defining career path and individual life trajectories. Today's academic performance continues to be understood as a precise proxy for aptitude and is a core determinant of career paths and achievement even though some doubt its value (ChammorePremuzic and Furnham, 2010).

\section{Factors that motivate and sustain teachers' interest}

Motivational factors for teachers towards active learning process play a vital role to facilitate his/her profession for national development

1. Internet facility: A teacher should have the facility of internet to accomplish his needs to create new activities, meaning and usage of words, problematic terms, pictures of every world, learning methodologies, preparation of low cost and no cost material, enrich with day by day initiative, handling with perfection so that teacher will give positive and constructive results.

2. Salary package: teachers must be improved according to the skills, creativity, enrollment of students and environmental factors in which he works. His credibility, importance in school, worth for society and most important his results of his class. He must have courage to improve all these factors with facilitative way.

3. Department should trust on the teachers and their work. Department should not underestimate them. They should have free hand to work and complete objectives.

4. Promotion: the adequate promotion of teachers has a positive impact in discharging their duties effectively and efficiently, thus this leads to teachers' high standard of living and sometimes makes him to carry out his work enthusiastic. 
50| Jurnal Office: Jurnal Pemikiran Ilmiah dan Pendidikan Administrasi Perkantoran

Vol. 6, No. 1, January-June 2020, Page 45-52

5. Priority of Teachers welfare: Consideration of teachers' welfare will foster their service. It will make teachers to put in their best.

\section{CONCLUSION}

The establishment of seminars workshops and conferences to teacher have a great impact in their teaching performance these programs will enable the teachers to improve the academic performance of the students in the classroom and they will also acquire more knowledge which will help them. Inadequate promotion of teachers poses a very big hindrance in discharging their duties effectively it leads to their low standard of living and hence, the lack some basic needs. Also it causes unseriousness of the teachers. The negligent of teachers' welfare emanated from all institutions and individuals concerned in education such as the government the external agencies like the communities and nongovernmental organization and even the individual who are directly involved in the school such as the school head and hence the (teacher) always have problems with them.

\section{REFERENCES}

Afe John .O. (2002).Reflection of becoming a teacher and the challeges of teacher education".

Ala Adeyemi and Afolabi F.O (1990). Job Satisfaction among primary school teachers' Naeap Jos P. 145.

Babatope, A.N. and Babato, J.K; (2012). Motivation of workers.journal of research in vocational and technical education. Vol. 7 No 15

Berelson, Band Steiner G.A (1964) Human behavior an inveulory of scientific findings New York Harcourt, brace and world.

Cole G.A (2000) Management theory and practice Lens educational aldine place London.

Federal government of Nigeria (1998) Reviewed National policy on education Lagos ministry of education Journal of quality education vol. 4 p 31

Fredrick H. (1993), The motivation work, New jersey transaction publishers.

Gardener, R.C. and Lambert W.E (1972), Attitudue and motivation in second language learning. Rouler, M.A. Newbury Hausa.

Kanu O.C (1997), Teacher's motivation as a viable option for the survival of Nigeria education system Journal of quality education vol $4 \mathrm{p} 187$

Maslow's A. (1954), Motivation and personality, New York, harper and Rows.

Ma'azu, M.T, and Onouha G.N (2012), The role of motivation and interest in the 4 teaching and learning process.contemporary issue in Education. A publication of the faculty of Education Nasarawa state University, keffi Nigeria.

Oluchukwu E.E (2002).Staff motivation towards effective Job performance in Nigeria schools. Teachers Net Gazette vol 1 No 6. 
Richard M, Steer L, Porter W. (1983), Motivation and work behavior. New York MC Graw Hill.

Shuaibu F.B. (2006). Effect of Teacher motivation on academic performance of Secondry School Students in Abuja F.C.T. Abuja journal of education vol.7 No. 1.

Weiner, B (1979). A theory of motivation for some classroom experiences. Journal of education psychology.

Irek, N. E. (2018). Advertising as an Effective Promotional Tool for Theatre Marketing in Nigeria. Nsukka Ikenga International Journal of Institute of African Studies, 18(1).

Adora, C. U., \& Irek, N. E. (2015). Interrogating the Indifferences In The Application Of Statistical Techniques In Theatre Scholarship. Nsukka Ikenga International Journal of Institute of African Studies, 18(1).

Irek, N. E., \& Charles, E. (2015). Theatre Practice in Nigeria: Surveying the Past and Present. Ifok Journal of Interdisciplinary Studies, 2(1). 
$52 \mid$ Jurnal Office: Jurnal Pemikiran Ilmiah dan Pendidikan Administrasi Perkantoran Vol. 6, No. 1, January-June 2020, Page 45-52 